\title{
Influence of Packaging on Quality Retention of Longans (Dimocarpus longan) Under Constant and Fluctuating Postharvest Temperatures
}

\author{
Marisa M. Wall ${ }^{1}$, Kate A. Nishijima, and Lisa M. Keith \\ U.S. Department of Agriculture, Agricultural Research Service, U.S. Pacific \\ Basin Agricultural Research Center, 64 Nowelo Street, Hilo, HI 96720
}

\begin{abstract}
Mike A. Nagao
Beaumont Agricultural Research Center, College of Tropical Agriculture and Human Resources, University of Hawaii, 875 Komohana Street, Hilo, HI 96720

Additional index words. Sapindaceae, tropical fruit, postharvest, modified atmosphere packaging
\end{abstract}

\begin{abstract}
Longan (Dimocarpus longan) fruit production and global exports are rapidly expanding. Consumer acceptance of this high value crop requires that fruit arrive in excellent condition. Pericarp browning and fungal diseases are the main postharvest problems for longans. Research was conducted to establish optimum storage temperatures and packaging systems to retain fruit quality of 'Biew Kiew' longans. Average respiration rates for longans stored at $20^{\circ} \mathrm{C}\left(61.6 \mathrm{mg} \mathrm{CO}_{2} / \mathrm{kg} / \mathrm{h}\right)$ were about twice the rate as those stored at $10^{\circ} \mathrm{C}(32.7 \mathrm{mg} \mathrm{CO} / \mathrm{kg} / \mathrm{h})$ and triple the rate for those stored at $5{ }^{\circ} \mathrm{C}$ $(21.1 \mathrm{mg} \mathrm{CO} / / \mathrm{kg} / \mathrm{h})$. Ethylene rates were below $0.4 \mu \mathrm{g} \cdot \mathrm{kg}^{-1} \cdot \mathrm{h}^{-1}$. Fruit quality and shelf life were greatest when stored at $10^{\circ} \mathrm{C}$. Longans held at $20^{\circ} \mathrm{C}$ were unmarketable after $10 \mathrm{~d}$, and fruit stored at $5{ }^{\circ} \mathrm{C}$ exhibited chilling injury (CI). After storage at $10{ }^{\circ} \mathrm{C}$, longans packaged in microperforated (MP) bags, clamshell (CL) containers, or Peakfresh ${ }^{\circledR}$ film (PF) had the highest visual quality ratings, lowest disease incidences, and longest shelf life when compared with fruit in Lifespan ${ }^{\circledR}$ film (LS) or fiberboard boxes. The most promising packages (MP, CL, PF) were evaluated further under constant $10{ }^{\circ} \mathrm{C}$ or simulated shipping (SS) conditions with fluctuating temperatures $\left(22^{\circ} \mathrm{C} / 10{ }^{\circ} \mathrm{C} / 22^{\circ} \mathrm{C}\right)$. Longans in $C L$ containers had the highest visual quality and lowest disease incidence when stored at $10^{\circ} \mathrm{C}$, but there were no differences among package treatments under SS conditions. Also, sensory ratings were greatest for fruit packed in CL or PF when stored at $10{ }^{\circ} \mathrm{C}$ but all sensory scores decreased under SS temperatures. When longans were stored under fluctuating temperatures, aril texture and flavor ratings were highest for CL packages. CL, PF, and MP are suitable packages for longans stored under optimal temperatures. However, for longans stored under SS conditions, sensory quality was highest when packaged in CL containers.
\end{abstract}

Longan (Dimocarpus longan Lour.) is a subtropical fruit of the Sapindaceae originating from Burma to southern China (Nakasone

Received for publication 28 Mar. 2011. Accepted for publication 24 Apr. 2011.

This research was supported by the USDA Special Research Grant for Agricultural Diversification: Hawaii Tropical Specialty Fruit Research and Development and by the USDA Agricultural Research Service.

We acknowledge the excellent technical assistance of Darson Aoki, Andrea Lysy, Suzanne Sanxter, Sandra Silva, and Lionel Sugiyama and the cooperation of the Hawaii Tropical Fruit Grower's Assoc., Onomea Farms, and Hula Bros., Inc.

Mention of a trademark, warranty, proprietary product, or vendor does not constitute a guarantee by the U.S. Department of Agriculture and does not imply its approval to the exclusion of other products or vendors that may be suitable.

${ }^{1}$ To whom reprint requests should be addressed; e-mail marisa.wall@ars.usda.gov. and Paull, 1998; Tongdee, 1997). The fruit has a thin, light brown rind surrounding a sweet, white aril with a black seed. Longans are a rich source of vitamin $\mathrm{C}$, minerals, and bioactive polyphenols (Wall, 2006; Yang et al., 2010). Important production areas are Southern China, Thailand, Taiwan, and Australia (Nakasone and Paull, 1998). Longan is grown in Hawaii, where production has expanded rapidly following the decline of the sugarcane plantations. Between 2001 and 2008 , the number of longan trees planted increased from 2300 to 11,800 with $65 \%$ at bearing age (National Agricultural Statistics Service, 2009). Year-round flowering of longan trees can be stimulated with potassium chlorate, facilitating a nearly continuous harvest season and orderly market supply (Nagao, 2009). Fruit are consumed locally and exported to U.S. mainland markets. Increased exports are needed to support the expansion in production. However, the fruit are hosts of the
Mediterranean fruit fly (Ceratitis capitata) and oriental fruit fly (Bactrocera dorsalis) and undergo quarantine treatment at an X-ray irradiation facility on Hawaii Island before export via air shipment.

Consumer acceptance of this high value crop requires that fruit arrive at their final destination in excellent condition with minimal defects. However, pericarp darkening and postharvest diseases typically limit longan shelf life. Although skin browning does not impact edible aril quality, it reduces the visual appearance and commercial value of the fruit. Postharvest diseases of longan are primarily caused by fungal pathogens (Coates et al., 2003). In Hawaii, Phomopsis sp., Pestalotiopsis sp., Colletotrichum sp., and Lasmenia sp. have been isolated from infected fruit (Keith, 2005; Wall et al., 2010). Sulfur dioxide fumigation is used in Asian countries to prevent peel browning and control diseases, but $\mathrm{SO}_{2}$ use is prohibited in the United States (Jiang et al., 2002). Longan fruit quality may be retained through modified atmosphere packaging (MAP) in which high humidity, high $\mathrm{CO}_{2}$, and low $\mathrm{O}_{2}$ levels are created inside semipermeable films through fruit respiration and transpiration (Kader et al., 1989). An industry analysis identified the development of postharvest technology involving MAP as a research priority for Sapindaceae fruit (Nagao, 2009). Although packaging reduces water loss, the humid atmosphere can cause greater postharvest diseases especially at higher temperatures, which may occur during retail marketing. Knowledge of $\mathrm{O}_{2}$ and $\mathrm{CO}_{2}$ levels within a package is important because levels beyond those tolerated by a commodity can induce physiological disorders or anaerobic respiration and off-flavor development (Kader et al., 1989).

Optimum temperatures must be maintained during postharvest handling to maximize shelf life and fruit quality, especially when MAP is used. However, ideal storage temperatures have not been clearly established for longans, and reports range from 1 to $10{ }^{\circ} \mathrm{C}$ at $90 \%$ to $95 \%$ relative humidity $(\mathrm{RH})$ (Drinnan, 2004; Jiang et al., 2002; Paull and Chen, 1987; Tian et al., 2002). Cultivars can differ in sensitivity to CI, modified atmospheres (MAs), and disease susceptibility, and the spectrum of fungi associated with diseased fruit can vary with storage temperature. Also, temperature fluctuations are common during shipping and retail handling and can impact the effectiveness of packaging. For these reasons, our research objectives were to determine the optimum storage temperature for 'Biew Kiew' longans, the most widely grown cultivar in Hawaii, and to evaluate different package types under controlled and variable temperature regimes to improve quality retention of exported longans.

\section{Material and Methods}

Storage temperatures. The first experiment in 2007 was designed to determine the optimum temperature range for storing 'Biew Kiew' longans. Longans were harvested from 
a commercial orchard in Keaau, HI, on 16 July 2007. The trees in this orchard and all subsequent locations had been induced to flower with potassium chlorate applications. About 6.5 to $7.5 \mathrm{~kg}$ fruit were harvested from each of four healthy trees. Fruit were removed from panicles and sorted. Fifty fruits (771 g) were packaged in MP bags (clear polypropylene, $500 \mathrm{~cm}^{2}, 25-\mu \mathrm{m}$ thick; Elkay Plastics, Inc., Los Angeles, CA) and placed in fiberboard boxes. Four replicates per temperature were stored in walk-in coolers at 5,10 , 15 , or $20^{\circ} \mathrm{C}$ for up to $16 \mathrm{~d}$. Fruit were evaluated for weight, surface color, external appearance, total soluble solids (TSS), titratable acidity (TA), and aril firmness at the beginning and end of the storage period. Also, fruit respiration and ethylene production rates were determined throughout storage at the four temperatures.

Packaging experiments. Two experiments were conducted in 2008 to determine packaging effects on longan quality for fruit stored at optimum $\left(10^{\circ} \mathrm{C}\right)$ temperature. Longans were harvested on 1 May and 20 Oct. 2008 from a commercial orchard in Onomea, HI. Fruit (1300 to $1500 \mathrm{~g}$ ) were placed into fiberboard boxes, MP bags, CL containers, LS bags, or $\mathrm{PF}$ bags and stored at $10^{\circ} \mathrm{C}$ for up to 3 weeks. Fruit in the CL, MP, LS, and PF packages were placed into fiberboard boxes for storage. Four to five blocks were used for each treatment. A block consisted of fruit harvested from an individual tree in the orchard.

The MP bags were the same as used for the July 2007 experiment. About $30 \%$ of the surface area was perforated with 1-mm-diameter microperforations. The CL containers were 3.3-L vented, recycled polyethylene terephthalate punnets (LINPAC Plastics, West Yorkshire, United Kingdom). LS bags were made from low density polyethylene (LDPE) film with properties that allow release of excess moisture $\left(1920 \mathrm{~cm}^{2}, 20-\mu \mathrm{m}\right.$ thick; courtesy of Amcor, Hawthorne, Victoria, Australia). PF film is a LDPE impregnated with a natural mineral, which reportedly absorbs ethylene gas and maintains high humidity while minimizing condensation (PeakFresh USA, Anaheim, CA). The PF packages were $1200 \mathrm{~cm}^{2}$ and 35- $\mu \mathrm{m}$ thick. The $\mathrm{CO}_{2}$ and $\mathrm{O}_{2}$ permeance rates for LS and PF films were measured by Mocon (Minneapolis, MN) at $10{ }^{\circ} \mathrm{C}$ and $90 \% \mathrm{RH}$, and units were converted according to Banks et al. (1995). LF permeance for $\mathrm{CO}_{2}$ was $5.330 \times 10^{-13} \mathrm{~mol} \cdot \mathrm{s}^{-1} \cdot \mathrm{m}^{-2} \cdot \mathrm{Pa}^{-1}$ and for $\mathrm{O}_{2}$ was $1.271 \times 10^{-13} \mathrm{~mol} \cdot \mathrm{s}^{-1} \cdot \mathrm{m}^{-2} \cdot \mathrm{Pa}^{-1}$. The $\mathrm{CO}_{2}$ permeance for PF was $4.430 \times 10^{-11}$ $\mathrm{mol} \cdot \mathrm{s}^{-1} \cdot \mathrm{m}^{-2} \cdot \mathrm{Pa}^{-1}$, and the $\mathrm{O}_{2}$ permeance was $7.176 \times 10^{-12} \mathrm{~mol} \cdot \mathrm{s}^{-1} \cdot \mathrm{m}^{-2} \cdot \mathrm{Pa}^{-1}$.

Packaging treatments under constant or variable temperature regimes. 'Biew Kiew' fruit were harvested on 4 Nov. 2009 and 24 Mar. 2010 from the Waiakea Agricultural Experiment Station, Hilo, HI, and placed in the most promising package types identified in the 2008 experiments. Longans ( 1 to 1.2 $\mathrm{kg}$ ) were packaged in CL, MP, or PF and stored under two temperature regimes: control or SS. The control treatment was constant $10{ }^{\circ} \mathrm{C}$ for $14 \mathrm{~d}$. The SS treatment was $2 \mathrm{~d}$ at
$22{ }^{\circ} \mathrm{C}$ (simulated harvest, packing, quarantine treatment, and air transport temperature), transferred to $10{ }^{\circ} \mathrm{C}$ for $10 \mathrm{~d}$ (simulated wholesale storage and distribution temperature), and removed to $22{ }^{\circ} \mathrm{C}$ for $2 \mathrm{~d}$ (simulated retail conditions).

Gas analyses. For the storage temperature experiment (2007), respiration and ethylene production rates were analyzed using a gas chromatograph (GC) (GC-14B; Shimadzu, Kyoto, Japan). Ten fruit from each replicate were selected and marked for use in measuring respiration gases throughout the storage trial. Each set of fruit was placed in a 1-L glass jar with a lid fitted with a septum. The GC was equipped with a Poropak QS stainless steel column (100-120 mesh; Supelco, Bellefonte, PA), a thermal conductivity detector for $\mathrm{CO}_{2}$ detection, and a flame ionization detector for ethylene detection. Helium was the carrier gas at $50 \mathrm{kPa}$, and temperatures were set at $60^{\circ} \mathrm{C}$ for the column and $100{ }^{\circ} \mathrm{C}$ for both detectors. The run time was $5 \mathrm{~min}$.

For packaging experiments, $\mathrm{CO}_{2}$ and $\mathrm{O}_{2}$ levels were analyzed in each package using a headspace analyzer (model 6600; Illinois Instruments, Johnsburg, IL). Packages were fitted with septa for gas sampling. Measurements were taken for each replicate of all package types at the beginning of experiments and at 2- to 3-d intervals until the end of shelf life. Gas measurements were ended for box, MP, and CL packages at day 9, when results indicated no differences from ambient atmosphere.

Quality analyses. Fruit from all harvest dates (2007-2010) were evaluated for disease incidence, soluble solids content, total acidity, weight loss, aril firmness, pericarp color, and external appearance. Evaluations were done on the day of harvest and packaging (day 0 ) and at the end of shelf life for all quality factors. Also, surface color measurements and visual ratings were taken at 3- to 5-d intervals. Shelf life was determined when the external quality rating was 3 (average). Peel color of 10 individual fruit per replicate treatment was measured using a colorimeter (model CR-300; Minolta Corp., Ramsey, NJ) and recorded as lightness $\left(L^{*}\right)$, chroma $\left(C^{*}\right)$, and hue angle $\left(H^{\circ}\right)$ under standard illuminant C. Fruit (50 per replicate) were visually evaluated for quality using a discoloration scale based on the percentage discoloration of the fruit surface area where $5=$ excellent (no discoloration), $4=\operatorname{good}($ slight discoloration), $3=$ average $(<25 \%$ discoloration), 2 = below average ( $25 \%$ to $50 \%$ discoloration), and $1=$ poor $(>50 \%$ discoloration). Aril firmness (Newtons) of 10 individual fruit was measured using a digital motorized force gauge (Chatillon LTCM100; Ametek, Largo, FL) with a 6-mmdiameter conical probe. Soluble solids content (TSS) of the aril tissue (10 fruit) was measured
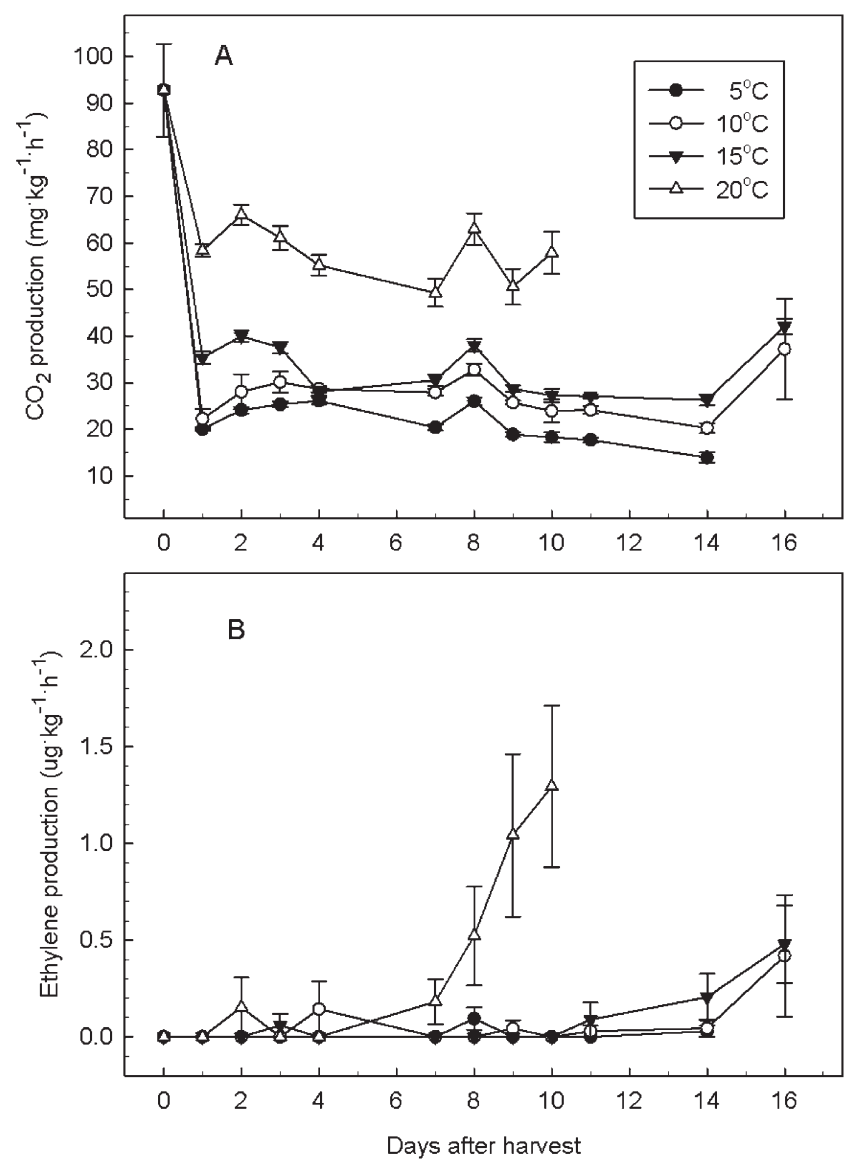

Fig. 1. Respiration and ethylene production rates for 'Biew Kiew' longans packaged in microperforated bags and stored at four different temperatures. Bars represent SES. 
using a digital refractometer (Atago, Kirkland, WA) at the start and end of each storage period. Acidity (TA) was determined by titrating the composite juice sample of 10 fruit to a final $\mathrm{pH}$ of 8.1 with $0.01 \mathrm{~N} \mathrm{NaOH}$ and calculated as citric acid equivalents.

Disease evaluations and identifications. Disease severity of 50 fruit was rated according to the fruit surface area with symptoms where $1=$ slight $(<25 \%), 2=$ moderate $(26 \%$ to $50 \%)$, and $3=$ severe $(>50 \%)$. Disease incidence of each fruit was based on the number of fruit with disease symptoms having a severity rating of 2 for 50 randomly selected fruit. Isolations were made from five fruit with disease symptoms randomly selected from each replicate. Discolored sections $\left(2-\times 3-\mathrm{mm}^{2}\right.$ pieces $)$ of the fruit pericarp and/or fruit aril tissue were aseptically dissected, soaked $1.5 \mathrm{~min}$ in $0.5 \%$ sodium hypo- chlorite solution with a trace of detergent and drained on a clean laboratory tissue. Tissue pieces were placed on water agar and then incubated at $24{ }^{\circ} \mathrm{C}$ under continuous fluorescent illumination. Hyphal tip isolations were made from fungal growth on water agar plates and transferred to potato dextrose agar plates. Plates were incubated at $24{ }^{\circ} \mathrm{C}$ under continuous fluorescent illumination. Fungal identifications were based upon mycological and culture characteristics of sporulating strains.

Sensory evaluations. A sensory panel evaluated fruit appearance, texture, and flavor for the most promising MAP treatments in 2009 and 2010. In Nov. 2009, 24 panelists evaluated 28 sets of longan samples. A set included fruit stored for $14 \mathrm{~d}$ at $10{ }^{\circ} \mathrm{C}$ (control) or under variable temperatures (SS) and packaged in CL, MP, or PF. Similarly, 21 panelists evaluated 42 fruit sets in Mar. 2010 for longans

Table 1. Quality of 'Biew Kiew' longans after storage at four different temperatures.

\begin{tabular}{lcccccccc}
\hline Temp. & & $\begin{array}{c}\text { Soluble } \\
\left({ }^{\circ} \mathrm{C}\right)\end{array}$ & Day & scidity & Firmness & Visual & \multicolumn{3}{c}{ Peel color $^{\mathrm{y}}$} \\
\cline { 7 - 9 } & & $(\%)$ & $(N)$ & rating $^{z}$ & $L^{*}$ & $C^{*}$ & $H^{\circ}$ \\
\hline Initial & 0 & $18.2 \mathrm{a}^{\mathrm{x}}$ & $0.04 \mathrm{~b}$ & $4.2 \mathrm{a}$ & $5.0 \mathrm{a}$ & $48.9 \mathrm{a}$ & $29.5 \mathrm{a}$ & $87.2 \mathrm{a}$ \\
5 & 14 & $18.5 \mathrm{a}$ & $0.05 \mathrm{~b}$ & $4.2 \mathrm{a}$ & $1.9 \mathrm{c}$ & $37.3 \mathrm{c}$ & $22.6 \mathrm{c}$ & $72.0 \mathrm{c}$ \\
10 & 16 & $17.9 \mathrm{a}$ & $0.04 \mathrm{~b}$ & $3.9 \mathrm{a}$ & $2.4 \mathrm{~b}$ & $44.4 \mathrm{~b}$ & $24.5 \mathrm{~b}$ & $79.3 \mathrm{~b}$ \\
15 & 16 & $18.3 \mathrm{a}$ & $0.05 \mathrm{~b}$ & $4.1 \mathrm{a}$ & $1.8 \mathrm{c}$ & $43.9 \mathrm{~b}$ & $23.4 \mathrm{bc}$ & $79.3 \mathrm{~b}$ \\
20 & 10 & $18.5 \mathrm{a}$ & $0.07 \mathrm{a}$ & $3.9 \mathrm{a}$ & $2.3 \mathrm{bc}$ & $43.7 \mathrm{~b}$ & $22.7 \mathrm{c}$ & $78.3 \mathrm{~b}$ \\
\hline
\end{tabular}

${ }^{\mathrm{z}}$ Visual ratings were based on the percentage of the surface area exhibiting discoloration, where $5=$ excellent (no discoloration), $4=$ good (slight discoloration), $3=$ average $(<25 \%$ discoloration $), 2=$ below average ( $25 \%$ to $50 \%$ discoloration), and $1=$ poor ( $>50 \%$ discoloration).

${ }^{y}$ Lightness $\left(L^{*}\right)$ is on a scale of 0 to 100 . Chroma $\left(C^{*}\right)$ is on a scale of 0 to 60 , with full saturation at 60 . A hue angle $\left(H^{\circ}\right)$ of $90^{\circ}=$ yellow .

${ }^{x}$ Values are means of 40 observations, except for titratable acidity which was measured on four composite samples of 10 fruit. Mean separation within columns by Waller-Duncan $k$-ratio $t$ test, $(P \geq 0.05)$.

stored under constant or variable temperature regimes. Each set contained fruit from the three packaging types (CL, MP, PF) presented in separate, randomly numbered trays. Three fruit per treatment were evaluated by each panelist. Panelists rated the appearance, texture, and taste for each fruit set on a hedonic scale ranging from 1 through 9 , where $1=$ poor and $9=$ excellent. A poor (1) rating indicated a dark or moldy appearance, a very soft and watery texture, or a strong off-flavor taste. An excellent (9) rating was reserved for fruit with a fresh, yellow-green appearance, a very crisp and crunchy texture, or a very sweet and flavorful taste.

Statistical analyses. For packaging experiments, destructive quality data were subjected to analysis of variance using the general linear models (GLM) procedure (SAS Institute, 2002) for a randomized complete block design with four blocks for each treatment. A block consisted of fruit harvested from an individual tree in an orchard. Data for nondestructive measurements were analyzed for repeated measures over time using the GLM procedure. Data from the packaging treatments stored under different temperature regimes were analyzed using the GLM procedure for a split-plot design, with temperature regime as the main plot and package treatment as the subplot. The experiment was repeated once, with four replications per treatment. Data for each experiment were analyzed separately. After checking for homogeneity of variance, a combined analysis was performed for those variables where differences between experiments (harvest dates) were not significant and interactions
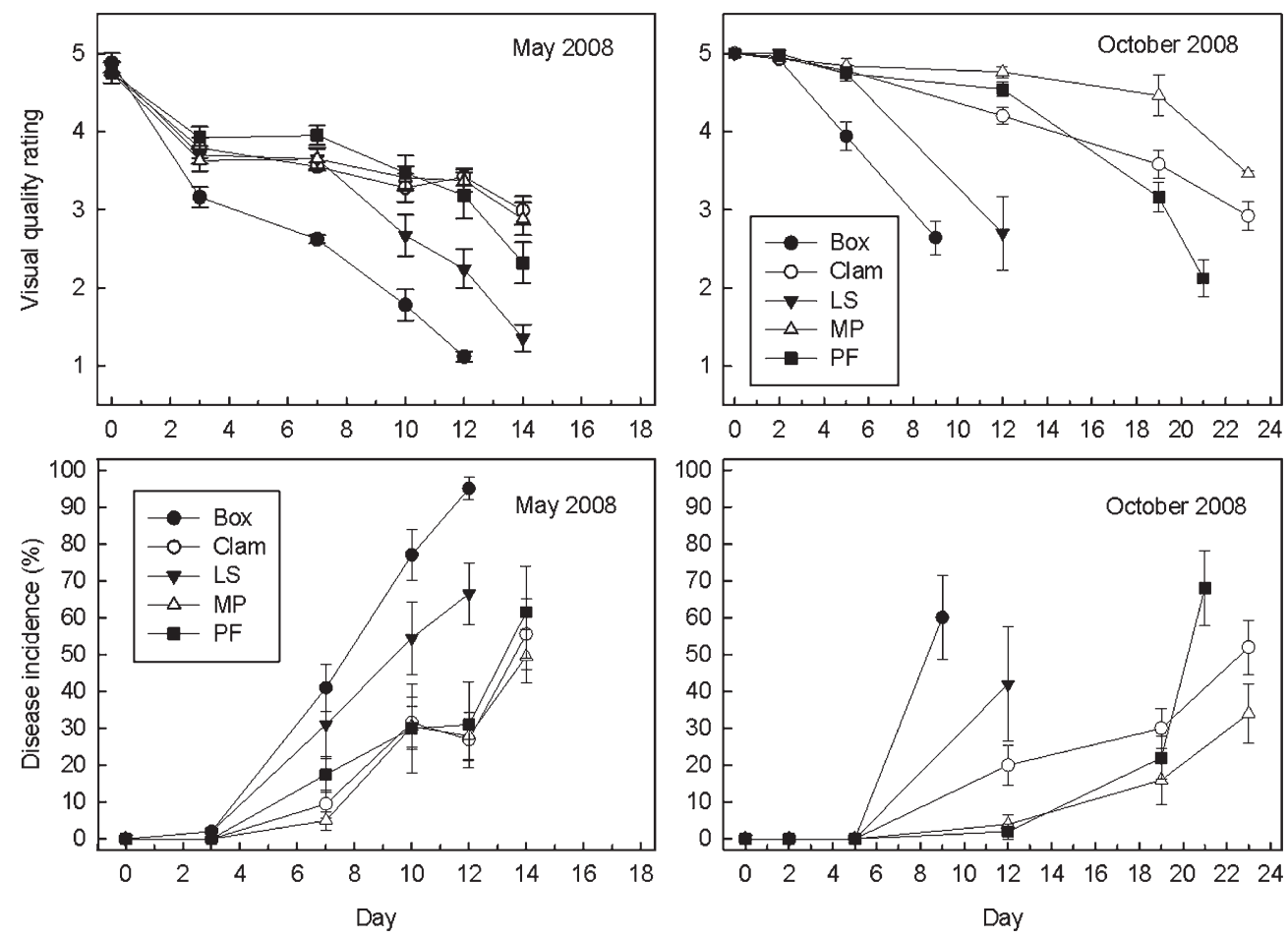

Fig. 2. Visual quality and disease incidences for 'Biew Kiew' longans harvested in May and Oct. 2008 and packaged in fiberboard boxes (Box), microperforated (MP) bags, clamshell containers (CL), LifeSpan ${ }^{\circledR}(\mathrm{LS})$ bags, or Peakfresh ${ }^{\circledR}(\mathrm{PF})$ bags and stored at $10^{\circ} \mathrm{C}$. Visual ratings were based on the percentage of the surface area exhibiting discoloration, where $5=$ excellent (no discoloration), $4=$ good (slight discoloration), $3=$ average $(<25 \%$ discoloration), $2=$ below average ( $25 \%$ to $50 \%$ discoloration), and $1=$ poor ( $>50 \%$ discoloration). Bars represent SES. 
between experiment and main factors were not significant. For main effects, mean separations were according to the Waller-Duncan $k$-ratio $t$ test $(P=0.05)$. When interactions among treatments were significant, pairwise comparisons using least square differences were used to determine differences among treatment means.

\section{Results and Discussion}

Storage temperatures (2007). Longan fruit are nonclimacteric and harvested when fully mature based on pericarp color and soluble solids content. On the day of harvest, 'Biew Kiew' fruit respiration rates were $92.8 \mathrm{mg}$ $\mathrm{CO}_{2} / \mathrm{kg} / \mathrm{h}$ but decreased to $58.3 \mathrm{mg} \mathrm{CO} / \mathrm{kg} / \mathrm{h}$ after $1 \mathrm{~d}$ at $20^{\circ} \mathrm{C}$ (Fig. 1A). This indicates that a modest temperature decrease can remove significant field heat from the crop in the tropics. No ethylene production was detected on harvest day (Fig. 1B). Average respiration rates for longans stored at $20^{\circ} \mathrm{C}(61.6 \mathrm{mg} \mathrm{CO} / \mathrm{kg} / \mathrm{h})$ were about twice the rate as those stored at $10{ }^{\circ} \mathrm{C}(32.7 \mathrm{mg} \mathrm{CO} / / \mathrm{kg} / \mathrm{h})$ and triple the rate for those stored at $5{ }^{\circ} \mathrm{C}(21.1 \mathrm{mg} \mathrm{CO} / \mathrm{kg} / \mathrm{h})$. Ethylene rates remained below $0.4 \mu \mathrm{g} \cdot \mathrm{kg}^{-1} \cdot \mathrm{h}^{-1}$ at all temperatures except $20^{\circ} \mathrm{C}$ (Fig. 1B), at which an increase in ethylene production was associated with postharvest decay. This is the first report of 'Biew Kiew' respiration and ethylene production rates. Other longan cultivars respired at lower rates, ranging from $\approx 20$ to $60 \mathrm{mg} \mathrm{CO} / \mathrm{kg} / \mathrm{h}$ at $10{ }^{\circ} \mathrm{C}$ and $20{ }^{\circ} \mathrm{C}$, respectively (Ketsa and Paull, 2004; Liao et al., 1983).

The quality and shelf life of 'Biew Kiew' longans were greatest when stored at $10{ }^{\circ} \mathrm{C}$ (Table 1). Fruit held at 20 or $15{ }^{\circ} \mathrm{C}$ were unmarketable after 10 or $16 \mathrm{~d}$, respectively, and longans stored at $5{ }^{\circ} \mathrm{C}$ exhibited CI. CI symptoms for 'Biew Kiew' fruit were dark brown blemishes on the outer and inner peel surfaces. Therefore, the visual rating and surface color $\left(L^{*}, C^{*}, H^{\circ}\right)$ of fruit stored at $5{ }^{\circ} \mathrm{C}$ were lower than the fruit stored at $10{ }^{\circ} \mathrm{C}$ (Table 1). A similar result was reported by Drinnan (2004), where 'Biew Kiew' fruit showed obvious chilling damage at 5 and 7.5 ${ }^{\circ} \mathrm{C}$ and slight injury at $10{ }^{\circ} \mathrm{C}$. Other cultivars may be stored at lower temperatures than 'Biew Kiew'. 'Shixia' longans tolerated $1{ }^{\circ} \mathrm{C}$, whereas 'Wuyuan' fruit could be stored at 2.5 ${ }^{\circ} \mathrm{C}$ (Jiang, 1999). The CI threshold was 6.5 to $7.5^{\circ} \mathrm{C}$ for 'Homestead', $7.5^{\circ} \mathrm{C}$ for 'Kohala', and 7.0 to $8.0{ }^{\circ} \mathrm{C}$ for 'Chompoo' (Drinnan, 2004).

After 10-d storage, weight loss was less than $2 \%$ at 5 and $10{ }^{\circ} \mathrm{C}$ but was $4 \%$ to $6 \%$ at 15 and $20^{\circ} \mathrm{C}$, respectively (data not shown). At harvest 'Biew Kiew' arils were firm (4.2 $\mathrm{N}$ ), with $18.2 \%$ TSS and $0.04 \%$ TA (Table 1 ). Aril quality was retained for fruit stored at all temperatures, except that higher TA was measured in longans stored at $20^{\circ} \mathrm{C}$. Also, the external quality ratings were below average (visual rating $<3$ ) at 14 to $16 \mathrm{~d}$ for fruit stored at all temperatures. Therefore, the estimated shelf life (visual rating $\geq 3$ ) for summerharvested 'Biew Kiew' longans was shorter and ranged from 7 to $14 \mathrm{~d}$ for fruit held at 20 and $10{ }^{\circ} \mathrm{C}$, respectively. Fruit shelf life at $15^{\circ} \mathrm{C}$ was estimated as 10 to $12 \mathrm{~d}$. Based on these results, subsequent packaging trials were conducted at $10{ }^{\circ} \mathrm{C}$, the optimum storage temperature for 'Biew Kiew' longans.

Packaging treatments (2008). Longans varied in visual quality when harvested in May and Oct. 2008 from the same orchard (Fig. 2). Fruit harvested in May had an initial external rating of 4.8 vs. 5.0 (excellent) for the October harvest. As a result, shelf life tended to be shorter for fruits harvested in May. Shelf life was estimated as the number of days that fruit retained a visual quality rating $\geq 3$ (average). Fruit packaged in boxes had a short shelf life of 4 to $7 \mathrm{~d}$ when stored at $10^{\circ} \mathrm{C}$ (Fig. 2), whereas longans in MP or CL packages had the longest shelf life from $14 \mathrm{~d}$ (May) to $23 \mathrm{~d}$ (October). The shelf life of fruit packaged in PF film was $12 \mathrm{~d}$ (May) to $19 \mathrm{~d}$
(October), and considerably shorter with LS film (9 to $11 \mathrm{~d}$ ) (Fig. 2).

Changes in visual quality ratings during storage were confirmed with objective surface color measurements (Fig. 3; Oct. 2008). In general, visual quality ratings remained high during the first 12-d storage for longans stored in MP, PF, or CL packages (Fig. 2), and this was reflected most closely by the higher lightness $\left(L^{*}\right)$ and hue angle $\left(H^{\circ}\right)$ values for these treatments (Fig. 3). Conversely, skin browning was most evident in boxed fruit, which showed a rapid decrease in $L^{*}, C^{*}$, and $H^{\circ}$ values denoting a dark, dull, orange-brown color after 9-d storage. Longan browning is attributed to enzymatic oxidation of phenolics (epicatechin) by polyphenol oxidase (PPO) and is generally associated with desiccation, disease, CI, heat stress, and senescence (Jiang et al., 2002; Shi et al.,
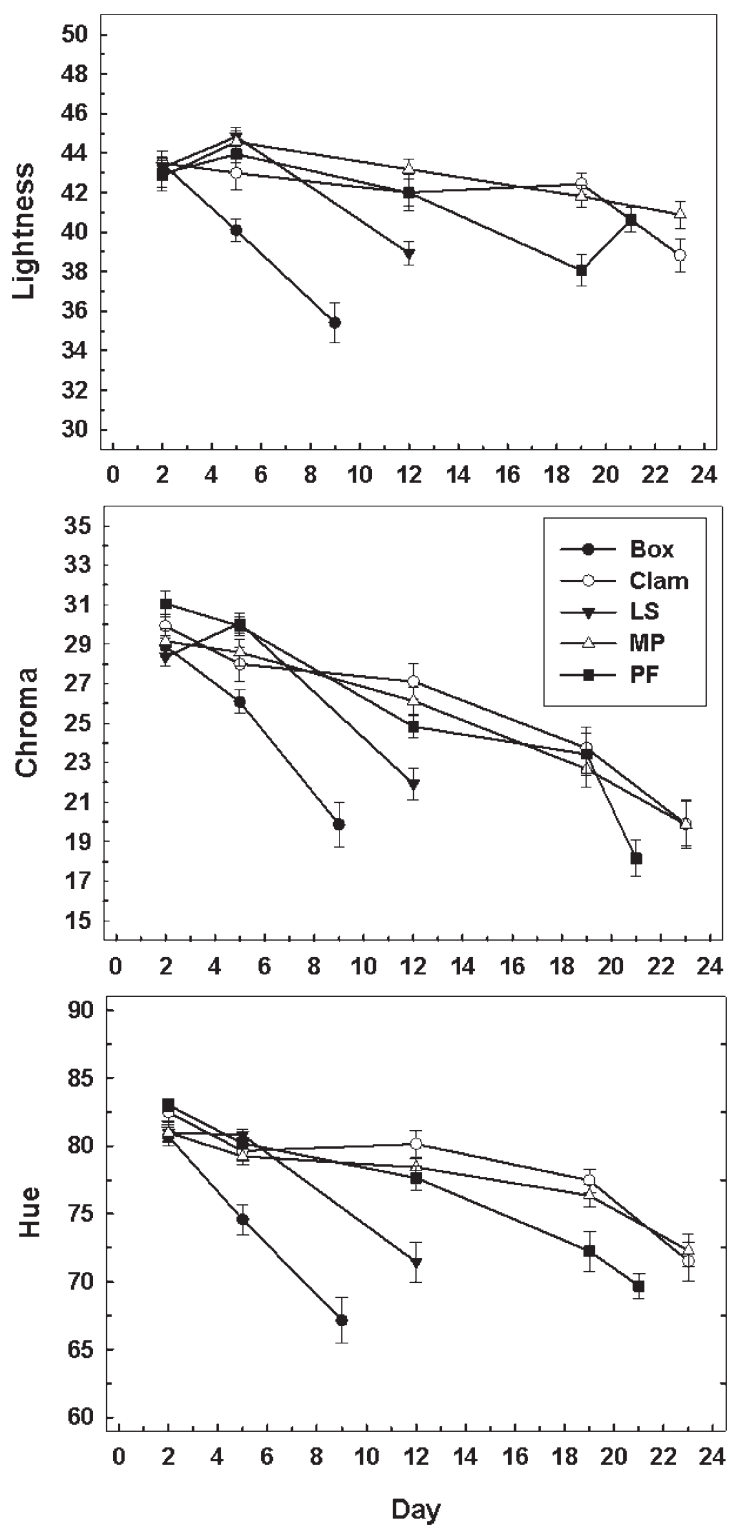

Fig. 3. Peel color of 'Biew Kiew' longans harvested in Oct. 2008 and packaged in fiberboard boxes (Box), microperforated (MP) bags, clamshell containers (CL), LifeSpan ${ }^{\circledR}(\mathrm{LS})$ bags, or Peakfresh ${ }^{\circledR}(\mathrm{PF})$ bags and stored at $10{ }^{\circ} \mathrm{C}$. Lightness $\left(L^{*}\right)$ is on a scale of 0 to 100 . Chroma $\left(C^{*}\right)$ is on a scale of 0 to 60 , with full saturation at 60 . A hue angle $\left(H^{\circ}\right)$ of $90^{\circ}=$ yellow. Bars represent SES. 
2008). PPO is induced by moisture loss, and treatments to reduce desiccation also minimize pericarp browning (Jiang et al., 2002), although high humidity and low airflow conditions accelerate postharvest decay (Drinnan, 2004). Various postharvest treatments have been shown to inhibit longan browning to some degree, including chitosan coatings, hydrochloric acid dips, nitric oxide exposure, high oxygen or $\mathrm{CO}_{2}$ atmospheres, and $\mathrm{N}$-acetyl-Lcysteine solutions (Apai, 2010; Duan et al., 2007; Jiang and Li, 2001; Sodchit et al., 2008; Su et al., 2005; Tian et al., 2002).

As expected, disease incidences increased with days in storage at $10{ }^{\circ} \mathrm{C}$ and differed between harvest dates and among packaging treatments (Fig. 2). Large tree-to-tree (block) variation in disease incidence was observed, especially for the May harvest (data not shown). Although rainfall was $47 \%$ of normal during March through Oct. 2008, the area received $99 \mathrm{~cm}$ of precipitation in February (440\% of normal rainfall), possibly initiating latent fungal infections on the fruit harvested in May. After 12-d storage, longans harvested in May and packaged in the CL, MP, and PF had $27 \%$ to $31 \%$ diseased fruit, whereas incidences were $67 \%$ and $95 \%$ for the LS and box treatments, respectively (Fig. 2). Longans harvested in Oct. 2008 also had the highest disease incidences when packaged in boxes or LS, but disease incidences were very low for fruit in PF $(2 \%)$ or MP (4\%) up to $12-\mathrm{d}$ storage. By day 19 , longans in MP, PF, and CL packages were $16 \%$ to $30 \%$ diseased (Fig. $2)$. For both harvest dates, disease severity ratings remained below 1 ( $<25 \%$ of fruit surface diseased) for fruit in MP, PF, and CL packages but averaged $3(>50 \%$ of surface area diseased) for box and LS packages (data not shown). Among fruit exhibiting disease symptoms, the most frequently isolated fungal pathogen was Phomopsis sp. (84\% to 97\%), followed by Pestalotiopsis sp. (12\% to 26\%) and Colletotrichum spp. (C. gloeosporioides and C. acutatum; $6 \%$ to $20 \%$ of diseased fruit). This was consistent with previous fungal isolations from longans in Hawaii (Keith, 2005; Wall et al., 2010). Others have reported postharvest diseases of longan caused by Diplodia (syn. Lasiodiplodia) theobromae, Phomopsis sp., anamorphs of Botryosphaeria spp., Pestalotiopsis sp., Cladosporium sp., and occasionally by Fusarium sp. and Aspergillus niger (Coates et al., 2003).

Longans packaged in PF bags had the lowest weight loss $(0.7 \%)$ after storage at $10{ }^{\circ} \mathrm{C}$ (Table 2), indicating that the pericarp remained hydrated. Weight loss ranged from $3 \%$ to $6 \%$ for the other package treatments. Although fruit in the MP or CL packages had $4 \%$ to $5 \%$ weight loss, they had slightly longer shelf life than longans in the PF film (Fig. 2; Table 2). This suggests that factors in addition to $\mathrm{RH}$ ( such as elevated $\mathrm{CO}_{2}$ ) contributed to retaining visual quality and low disease incidence up to $19 \mathrm{~d}$ for fruit packaged in PF. Gas concentrations inside MP or CL packages remained at ambient levels, whereas steady state $\mathrm{CO}_{2}$ and $\mathrm{O}_{2}$ levels reached $15 \mathrm{mPa}$ and $7 \mathrm{mPa}$, respec- tively, inside PF packages. Elevated $\mathrm{CO}_{2}$ in PF packages may have elicited a drop in pericarp $\mathrm{pH}$, thereby inhibiting fungal growth on packed fruit. For 'Shixia' longans, high $\mathrm{CO}_{2}$ atmospheres $\left(15 \mathrm{mPa} \mathrm{CO}_{2}\right.$ and $4 \mathrm{mPa}$ $\mathrm{O}_{2}$ ) also reduced decay and extended storage life (Tian et al., 2002).

Storage at $10{ }^{\circ} \mathrm{C}$ had a minor effect on fruit composition but longan arils tended to soften with time in storage. At harvest, longan fruit averaged $20.6 \%$ TSS and $0.06 \%$ TA, and the arils were crisp and firm $(5.8 \mathrm{~N})$ (Table 2$)$. After storage, TSS decreased slightly and ranged from $19 \%$ to $20 \%$, with small differences among package treatments. Firmness

Table 2. Quality of longans (cv. Biew Kiew) harvested in 2008 and stored at $10{ }^{\circ} \mathrm{C}$ in different package types.

\begin{tabular}{lccccc}
\hline Package & $\begin{array}{c}\text { Shelf life } \\
(\mathrm{d})^{\mathrm{z}}\end{array}$ & Wt loss $(\%)$ & $\begin{array}{c}\text { Soluble } \\
\text { solids }(\%)\end{array}$ & $\begin{array}{c}\text { Titratable } \\
\text { acids }(\%)\end{array}$ & Firmness $(\mathrm{N})$ \\
\hline Initial & - & - & $20.6 \mathrm{a}^{\mathrm{y}}$ & $0.06 \mathrm{a}$ & $5.8 \mathrm{a}$ \\
Clamshell & 23 & $4.77 \mathrm{~d}$ & $18.9 \mathrm{c}$ & $0.06 \mathrm{a}$ & $3.6 \mathrm{~d}$ \\
Microperforated & 23 & $4.09 \mathrm{c}$ & $19.2 \mathrm{bc}$ & $0.06 \mathrm{a}$ & $3.3 \mathrm{~d}$ \\
Peakfresh & 19 & $0.68 \mathrm{a}$ & $19.5 \mathrm{bc}$ & $0.04 \mathrm{~b}$ & $4.2 \mathrm{c}$ \\
Lifespan & 12 & $3.19 \mathrm{~b}$ & $19.6 \mathrm{bc}$ & $0.03 \mathrm{c}$ & $4.8 \mathrm{~b}$ \\
Box & 9 & $6.21 \mathrm{e}$ & $20.0 \mathrm{ab}$ & $0.04 \mathrm{~b}$ & $4.7 \mathrm{~b}$ \\
\hline
\end{tabular}

${ }^{2}$ Shelf life based on Oct. 2008 data.

${ }^{y}$ Values are means of 13 observations. Data were combined for May and Oct. 2008 experiments. Mean separations according to Waller-Duncan $k$-ratio $t$ test $(P \geq 0.05)$.

Table 3. External quality, disease incidence, and peel color of 'Biew Kiew' longans after storage at constant $10{ }^{\circ} \mathrm{C}$ or under fluctuating temperatures.

\begin{tabular}{|c|c|c|c|c|c|c|c|c|}
\hline \multirow{2}{*}{$\begin{array}{l}\text { Storage } \\
\text { temp. }\left({ }^{\circ} \mathrm{C}\right)\end{array}$} & \multirow[b]{2}{*}{ Package } & \multicolumn{2}{|c|}{ Visual rating ${ }^{2}$} & \multicolumn{2}{|c|}{ Disease incidence (\%) } & \multicolumn{3}{|c|}{ Peel color ${ }^{y}$} \\
\hline & & Day 7 & Day 14 & Day 7 & Day 14 & $L^{*}$ & $C^{*}$ & $H^{\circ}$ \\
\hline & & & & Nov. 2009 & & & & \\
\hline \multirow[t]{3}{*}{10} & $\mathrm{CL}$ & $3.8 \mathrm{a}^{\mathrm{x}}$ & $3.2 \mathrm{a}$ & $42.5 \mathrm{ab}$ & $73.8 \mathrm{a}$ & $44.8 \mathrm{a}$ & $25.4 \mathrm{a}$ & $74.8 \mathrm{a}$ \\
\hline & MP & $3.5 \mathrm{ab}$ & $2.1 \mathrm{~b}$ & $63.8 \mathrm{bc}$ & $92.5 \mathrm{~b}$ & $41.0 \mathrm{~b}$ & $21.2 \mathrm{~b}$ & $66.0 \mathrm{~b}$ \\
\hline & PF & $3.7 \mathrm{a}$ & $2.4 \mathrm{~b}$ & $56.3 \mathrm{~b}$ & $93.8 \mathrm{~b}$ & $45.8 \mathrm{a}$ & $28.1 \mathrm{a}$ & $72.5 \mathrm{a}$ \\
\hline \multirow[t]{3}{*}{$22 / 10 / 22$} & CL & $2.9 \mathrm{~b}$ & $1.8 \mathrm{~b}$ & $65.0 \mathrm{c}$ & $96.3 \mathrm{~b}$ & $41.3 \mathrm{~b}$ & $18.7 \mathrm{~b}$ & $66.4 \mathrm{~b}$ \\
\hline & MP & $3.7 \mathrm{a}$ & $1.8 \mathrm{~b}$ & $25.0 \mathrm{a}$ & $95.0 \mathrm{~b}$ & $41.4 \mathrm{~b}$ & $19.0 \mathrm{~b}$ & $64.8 \mathrm{bc}$ \\
\hline & $\mathrm{PF}$ & $2.2 \mathrm{~b}$ & $1.1 \mathrm{c}$ & $88.8 \mathrm{~d}$ & $100.0 \mathrm{~b}$ & $42.2 \mathrm{~b}$ & $18.6 \mathrm{~b}$ & $61.1 \mathrm{c}$ \\
\hline & & & & Mar. 2010 & & & & \\
\hline \multirow[t]{3}{*}{10} & CL & $4.5 \mathrm{a}$ & $4.4 \mathrm{a}$ & $20.0 \mathrm{a}$ & $16.3 \mathrm{a}$ & $47.2 \mathrm{a}$ & $26.8 \mathrm{~b}$ & $79.8 \mathrm{a}$ \\
\hline & MP & $3.8 \mathrm{a}$ & $3.7 \mathrm{~b}$ & $38.8 \mathrm{a}$ & $40.0 \mathrm{~b}$ & $45.7 \mathrm{~b}$ & $23.9 \mathrm{~d}$ & $75.4 \mathrm{bc}$ \\
\hline & $\mathrm{PF}$ & $4.2 \mathrm{a}$ & $3.9 \mathrm{ab}$ & $36.3 \mathrm{a}$ & $17.5 \mathrm{a}$ & $47.6 \mathrm{a}$ & $29.8 \mathrm{a}$ & $79.8 \mathrm{a}$ \\
\hline \multirow[t]{3}{*}{$22 / 10 / 22$} & $\mathrm{CL}$ & $4.3 \mathrm{a}$ & $3.5 \mathrm{~b}$ & $40.0 \mathrm{a}$ & $38.8 \mathrm{~b}$ & $46.6 \mathrm{a}$ & $25.0 \mathrm{c}$ & $77.3 \mathrm{~b}$ \\
\hline & MP & $4.0 \mathrm{a}$ & $3.6 \mathrm{~b}$ & $18.8 \mathrm{a}$ & $46.3 \mathrm{~b}$ & $45.7 \mathrm{~b}$ & $23.6 \mathrm{~d}$ & $74.5 \mathrm{c}$ \\
\hline & $\mathrm{PF}$ & $3.8 \mathrm{a}$ & $3.2 \mathrm{~b}$ & $40.0 \mathrm{a}$ & $46.3 \mathrm{~b}$ & $46.2 \mathrm{~b}$ & $25.8 \mathrm{bc}$ & $75.6 \mathrm{bc}$ \\
\hline
\end{tabular}

${ }^{2}$ Visual ratings were based on the percentage of the surface area exhibiting discoloration, where $5=$ excellent (no discoloration), $4=$ good (slight discoloration), $3=$ average $(<25 \%$ discoloration), $2=$ below average ( $25 \%$ to $50 \%$ discoloration), and $1=$ poor ( $>50 \%$ discoloration).

'Peel color values on day $14 . L^{*}=$ lightness, $C^{*}=$ chroma, $H^{\circ}=$ hue angle.

${ }^{x}$ Values are means of 40 observations. Mean separations within columns by pairwise comparisons using least square differences.

$\mathrm{CL}=$ clamshell containers; $\mathrm{MP}=$ microperforated; $\mathrm{PF}=$ Peakfresh ${ }^{\circledR}$.

Table 4. Percent weight loss, soluble solids, titratable acidity (TA), and aril firmness of 'Biew Kiew' longans after storage for $14 \mathrm{~d}$ at constant $10{ }^{\circ} \mathrm{C}$ or under fluctuating temperatures. ${ }^{z}$

\begin{tabular}{lccccc}
\hline $\begin{array}{l}\text { Storage } \\
\text { temp. }\left({ }^{\circ} \mathrm{C}\right)\end{array}$ & Package & $\begin{array}{c}\text { Wt loss } \\
(\%)\end{array}$ & $\begin{array}{c}\text { Soluble } \\
\text { solids }(\%)\end{array}$ & Acidity $(\%)$ & Firmness $(N)$ \\
\hline 10 & CL & $2.0 \mathrm{~b}$ & $21.9 \mathrm{a}$ & $0.06 \mathrm{a}$ & $4.2 \mathrm{a}$ \\
& MP & $3.4 \mathrm{c}$ & $21.8 \mathrm{a}$ & $0.06 \mathrm{a}$ & $3.9 \mathrm{ab}$ \\
& PF & $1.0 \mathrm{a}$ & $21.2 \mathrm{~b}$ & $0.05 \mathrm{a}$ & $3.8 \mathrm{ab}$ \\
& CL & $4.8 \mathrm{~d}$ & $21.5 \mathrm{ab}$ & $0.06 \mathrm{a}$ & $3.9 \mathrm{ab}$ \\
& MP & $6.9 \mathrm{e}$ & $21.6 \mathrm{ab}$ & $0.06 \mathrm{a}$ & $3.3 \mathrm{c}$ \\
& PF & $1.5 \mathrm{a}$ & $20.9 \mathrm{~b}$ & $0.04 \mathrm{~b}$ & $3.6 \mathrm{bc}$ \\
\hline
\end{tabular}

${ }^{\text {ZValues are means of eight measurements for weight loss, soluble solids, and TA and } 80 \text { observations for }}$ firmness. Data were combined for Nov. 2009 and Mar. 2010 experiments. Mean separations within columns by pairwise comparisons using least square differences. 
predominant organic acids in longan arils are succinic, malic, and citric acids present in a 10:5:1 ratio (Paull and Chen, 1987). 'Biew Kiew' longans also contain $\approx 63 \mathrm{mg}$ ascorbic acid per $100 \mathrm{~g}$ fresh weight at harvest (Wall, 2006), but ascorbic acid generally declines in aril tissue during storage (Jiang, 1999; Paull and Chen, 1987; Tian et al., 2002).

The 2008 packaging tests revealed that the postharvest quality of 'Biew Kiew' longans was maintained, overall disease incidence minimized, and shelf life extended when MP, CL, or PF packages were used in conjunction with storage at $10{ }^{\circ} \mathrm{C}$. Moderate humidity packaging that minimizes skin dehydration without wetting the fruit seems optimal for longans (Drinnan, 2004), and the MP, CL, and PF packages appeared to meet these conditions. Furthermore, the MA of the PF package could account for some of the beneficial effects on quality retention. The 2008 experiments were conducted under the ideal storage temperature for 'Biew Kiew' longans, demonstrating the potential quality and shelf life under near-optimal conditions. However, temperature fluctuations are common during the postharvest chain and can impact the effectiveness of packaging. For these reasons, the most promising packages (MP, CL, PF) were included in further studies in which the fruit were held at constant $10{ }^{\circ} \mathrm{C}$ (control) or under a regime that simulated temperatures encountered from harvest and quarantine treatment through shipping, storage, and retail handling $\left(2 \mathrm{~d}\right.$ at $22^{\circ} \mathrm{C}, 10 \mathrm{~d}$ at $10{ }^{\circ} \mathrm{C}, 2 \mathrm{~d}$ at $22^{\circ} \mathrm{C}$ ).

Packaging treatments under fluctuating temperatures (2009-2010). Similar to fruit harvested in 2008, seasonal differences in visual quality and disease incidence were observed for longans harvested in Nov. 2009 and Mar. 2010 (Table 3). After 14-d storage, only fruit in $\mathrm{CL}$ at $10{ }^{\circ} \mathrm{C}$ retained average visual quality in the November test, whereas all treatments had visual quality ratings $>3$ in the March test, regardless of temperature regime. The lower quality for the November harvest was related to much higher disease incidence, compared with the March harvest. Rainfall was $74 \%$ of normal during the 3 months before the Nov. 2009 harvest but only $31 \%$ of normal during Jan. to Mar. 2010. This may account for lower disease incidence for longans harvested in 2010. In March, fruit packaged in CL or PF had the lowest disease incidence after $14 \mathrm{~d}$ at $10{ }^{\circ} \mathrm{C}$ (Table 3). For both harvest dates, there were no disease differences among the package treatments when stored under the SS temperature regime. Peel color values showed that longans in CL or PF retained a lighter yellow color when compared with fruit in MP, especially at constant $10{ }^{\circ} \mathrm{C}$.

Seasonal effects were not evident for weight loss, composition, aril firmness, and sensory scores; therefore, data for these variables were combined for the 2009 and 2010 experiments. Longans stored in PF had the lowest weight loss under both temperature regimes. Fruit packaged in MP had the greatest weight loss and the softest arils under the
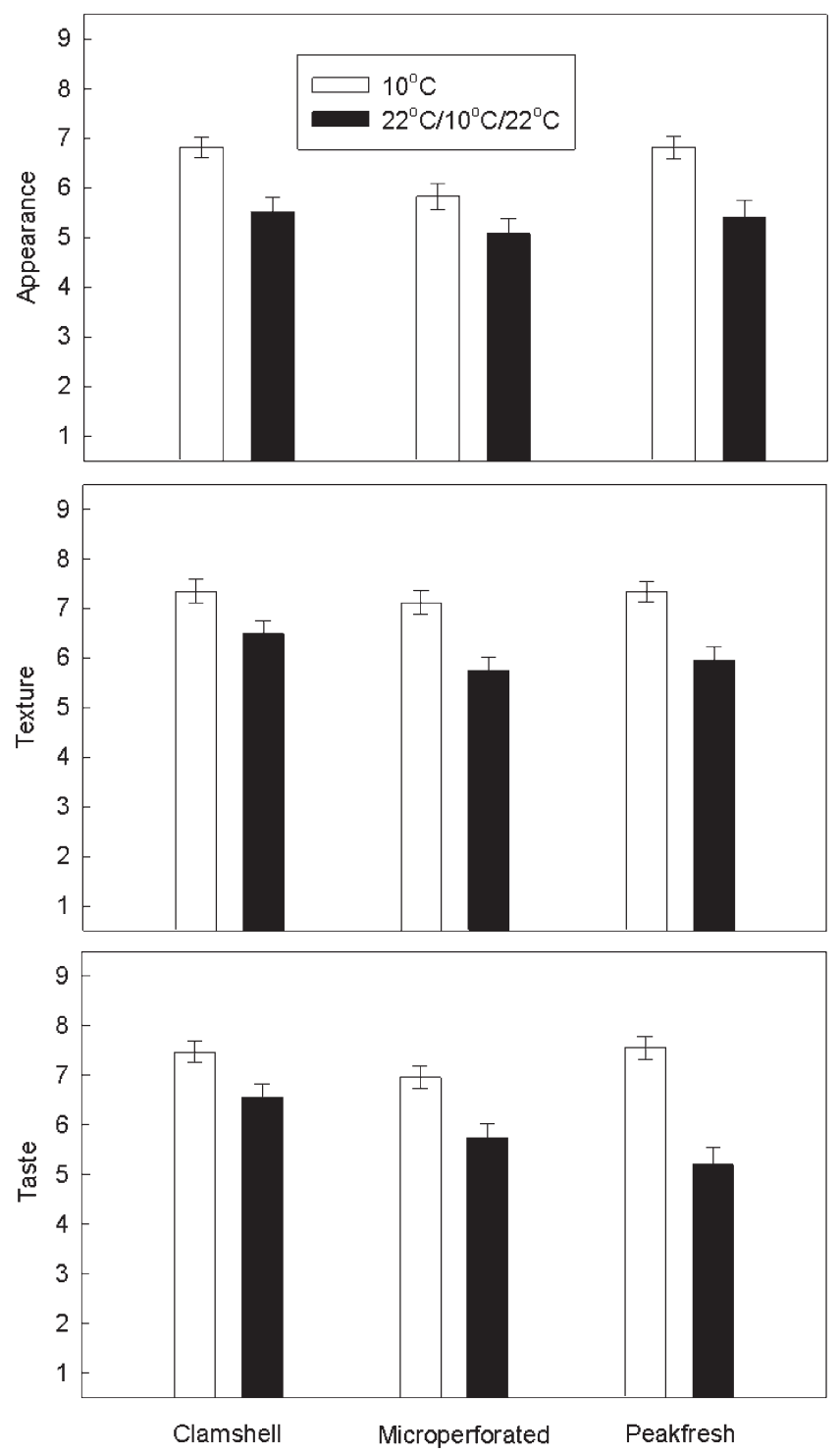

Fig. 4. Sensory quality of 'Biew Kiew' longans harvested in Nov. 2009 and Mar. 2010 and stored in clamshells, microperforated, or Peakfresh ${ }^{\circledR}$ packages at constant $10{ }^{\circ} \mathrm{C}$ for $14 \mathrm{~d}$ (control) or under a fluctuating temperature regime (simulated shipping) of $2 \mathrm{~d}$ at $22^{\circ} \mathrm{C}$, followed by $10 \mathrm{~d}$ at $10^{\circ} \mathrm{C}$ and $2 \mathrm{~d}$ at $22{ }^{\circ} \mathrm{C}$. Ratings were on a hedonic scale from 1 (least favorable) to 9 (most favorable). Bars represent SES.

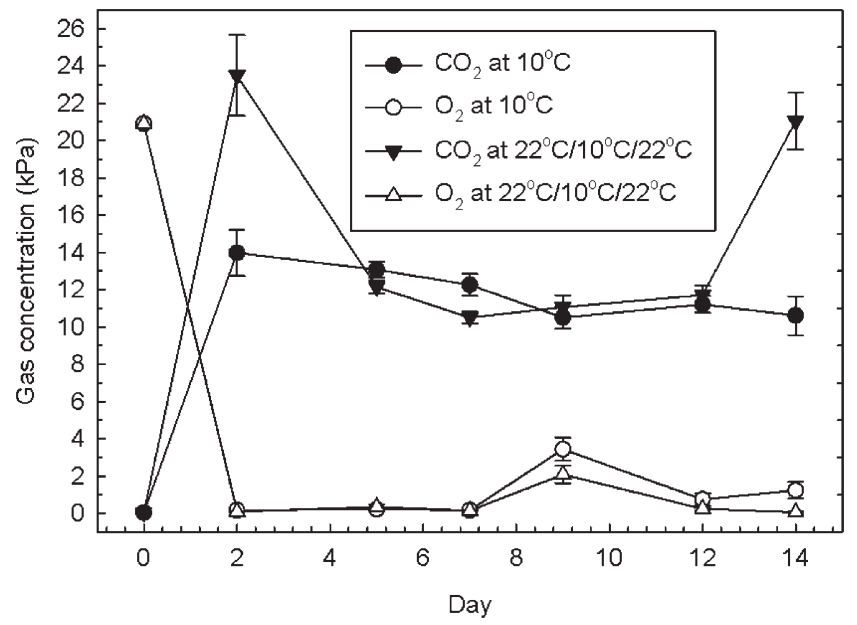

Fig. 5. Modified atmospheres $\left(\mathrm{CO}_{2}\right.$ and $\left.\mathrm{O}_{2}\right)$ inside Peakfresh ${ }^{\circledR}$ packages during 'Biew Kiew' longan storage at constant $10{ }^{\circ} \mathrm{C}$ (control) or under a fluctuating temperature regime (simulated shipping) of $2 \mathrm{~d}$ at $22{ }^{\circ} \mathrm{C}$, followed by $10 \mathrm{~d}$ at $10{ }^{\circ} \mathrm{C}$ and $2 \mathrm{~d}$ at $22^{\circ} \mathrm{C}$. Bars represent SES. 
SS temperatures (Table 4). There were minimal differences in TSS and TA among treatments, although the TA declined for fruit stored in PF under SS conditions. The physical and chemical changes were affirmed by the sensory panels (Fig. 4). After storage at constant $10{ }^{\circ} \mathrm{C}$, sensory panels rated the appearance of fruit in CL or PF as superior to longans packaged in MP, but otherwise there were no significant differences among package treatments (Fig. 4). Sensory quality declined overall when fruit were placed under SS conditions, as compared with $10{ }^{\circ} \mathrm{C}$. Most notably, fruit in CL had higher flavor scores than longans in MP or PF under SS temperatures.

Gas concentrations inside $\mathrm{CL}$ or MP packages remained at $21 \mathrm{kPa} \mathrm{O}_{2}$ and 0.04 $\mathrm{kPa} \mathrm{CO}_{2}$, regardless of temperature regime (data not shown), but were modified inside PF bags. At constant $10{ }^{\circ} \mathrm{C}$, steady state $\mathrm{CO}_{2}$ levels averaged $12 \mathrm{kPa}$ inside $\mathrm{PF}$ bags, but under the SS treatment $\mathrm{CO}_{2}$ levels reached 21 to $23.5 \mathrm{kPa}$ during the periods at $22{ }^{\circ} \mathrm{C}$ (Fig. $5)$. For both temperature regimes, $\mathrm{O}_{2}$ concentrations dropped below $1 \mathrm{kPa}$ inside $\mathrm{PF}$ packages during the first week of storage, and then rose 1 to $3 \mathrm{kPa}$ thereafter (Fig. 5). The MA may account for the slightly lower taste scores of longans packaged in PF and stored under SS temperatures (Fig. 4). MA of 1-5 $\mathrm{kPa} \mathrm{O}_{2}$ reportedly delays browning, aril breakdown, and decay, but $1 \mathrm{kPa} \mathrm{O}$ results in minor off-flavors (Cheng et al., 2009; Ketsa and Paull, 2004). For lychee, a related Sapindaceae crop, late-harvest fruit in MAP produced greater acetaldehyde and ethanol, and subsequently poorer flavor scores than early-harvest fruit (Pesis et al., 2002). This suggests that storage of fully or overripe fruit in MAP can lead to accumulation of anaerobic compounds and off-flavor development.

Rapid pericarp browning and postharvest decay remain the major limitations to longan shelf life and export to distant markets. Hawaii-grown longans typically are harvested, sorted, and packed in 8 to $10 \mathrm{lb}(3.6$ to $4.5 \mathrm{~kg}$ ) fiberboard boxes (fruit fly-free) lined with polyethylene or MP film. The fruit are irradiated to meet quarantine regulations and air-shipped to mainland U.S. distributors. These steps in the supply chain often take place within $48 \mathrm{~h}$ of harvest and without refrigeration. Wholesalers may then store fruit at $10{ }^{\circ} \mathrm{C}$ until retail marketing, when the surrounding temperature may rise again. Changes in temperatures during the postharvest chain make it difficult to maintain optimum atmospheres when using MAP. Packages are normally designed for specific, optimal temperatures (Brecht et al., 2003). Although the use of PF and MP films retained longan quality under constant $10{ }^{\circ} \mathrm{C}$, in general, fruit packed in CL containers tended to have firmer arils, lower disease incidence, and slightly higher flavor scores under fluc- tuating postharvest temperatures. Some seasonal differences were observed for longan fruit quality, disease incidence, shelf life, and response to packaging, possibly reflecting variations in preharvest conditions and maturity at harvest. Nevertheless, when considering multiple seasons and the two temperature regimes, 'Biew Kiew' longan shelf life and quality were consistently maintained when stored in CL packages. CL packages also may reduce fruit injury, restrict disease spread among punnets, and enable brand identification.

\section{Literature Cited}

Apai, W. 2010. Effects of dipping in hydrochloric acid then rinsing in water on fruit decay and browning of longan fruit. Crop Protection 29: 1184-1189.

Banks, N.H., D.J. Cleland, A.C. Cameron, R.M. Beaudry, and A.A. Kader. 1995. Proposal for a rationalized system of units for postharvest research in gas exchange. HortScience 30:11291131.

Brecht, J.K., K.V. Chau, S.C. Fonseca, F.A.R. Oliveira, F.M. Silva, M.C.N. Nunes, and R.J. Bender. 2003. Maintaining optimal atmosphere conditions for fruits and vegetables throughout the postharvest handling chain. Postharvest Biol. Technol. 27:87-101.

Cheng, G., Y. Jiang, X. Duan, A. Macnish, Y. You, and Y. Li. 2009. Effect of oxygen concentration on the biochemical and chemical changes of stored longan fruit. J. Food Qual. 32:2-17.

Coates, L.M., S. Sangchote, G.I. Johnson, and C. Sittigul. 2003. Diseases of longan, lychee and rambutan, p. 307-325. In: Ploetz, R.C. (ed.). Diseases of tropical fruit crops. CAB Intl., Wallingford, United Kingdom.

Drinnan, J. 2004. Longans: Postharvest handling and storage. A report for Rural Industries Research and Development Corp., RIRDC Publ. No. 03/125. Australia. 20 Jan. 2011. <https:// rirdc.infoservices.com.au/downloads/03-125>.

Duan, X., X. Su, Y. You, H. Qu, Y. Li, and Y. Jiang. 2007. Effect of nitric oxide on pericarp browning of harvested longan fruit in relation to phenolic metabolism. Food Chem. 104:571576.

Follett, P.A. and S.S. Sanxter. 2002. Longan quality after hot-water immersion and x-ray irradiation quarantine treatments. HortScience 37:571-574.

Jiang, Y. 1999. Low temperature and controlled atmosphere storage of fruit of longan (Dimocarpus longan Lour.). Trop. Sci. 39:98-101.

Jiang, Y. and Y. Li. 2001. Effects of chitosan coating on postharvest life and quality of longan fruit. Food Chem. 73:139-143.

Jiang, Y., Z. Zhang, D.C. Joyce, and S. Ketsa. 2002. Postharvest biology and handling of longan fruit (Dimocarpus longan Lour.). Postharvest Biol. Technol. 26:241-252.

Kader, A.A., D. Zagory, and E.L. Kerbel. 1989. Modified atmosphere packaging of fruits and vegetables. Crit. Rev. Food Sci. Nutr. 28:1-30.

Keith, L. 2005. Tropical fruit diseases: What's out there? Proc. XV Annu. Intl. Trop. Fruit Conf., Hilo, HI, p. 60.

Ketsa, S. and R.E. Paull. 2004. Longan. In: Gross, K.C., C.Y. Wang, and M. Salveit (eds.). Commercial storage of fruits, vegetables, and florist and nursery stocks. U.S. Dept. Agr., Agr. Res. Serv., Agric. Hdbk. No. 66. 7 Dec. 2010 $<\mathrm{http}: / /$ www.ba.ars.usda.gov/hb66/086longan. pdf $>$.

Liao, M.L., M.S. Liu, and J.S. Yang. 1983. Respiration measurement of some important fruits in Taiwan. Acta Hort. 138:227-246.

Lin, H.T., Y.F. Zhao, and Y.F. Xi. 2007. Changes in cell wall components and cell wall-degrading enzyme activities of postharvest longan fruit during aril breakdown. J. Plant Physiol. Molecular Biol. 33:137-145.

Nagao, M. 2009. Industry analysis: Identifying research and extension priorities for Hawaii's avocado, banana, citrus, and specialty fruits. Univ. Hawaii Coop. Ext. Serv. Bul. EI-17.

Nakasone, H.Y. and R.E. Paull. 1998. Tropical fruits. CAB Intl., Wallingford, United Kingdom.

National Agricultural Statistics Service. 2009. Hawaii tropical specialty fruits. 18 Sept. 2009. $<$ http://www.nass.usda.gov/Statistics_by_State/ Hawaii/Publications/Fruits_and_Nuts/tropfrt. pdf>.

Paull, R.E. and N.J. Chen. 1987. Changes in longan and rambutan during postharvest storage. HortScience 22:1303-1304

Pesis, E., O. Dvir, O. Feygenberg, R. Ben Arie, M. Ackerman, and A. Lichter. 2002. Production of acetaldehyde and ethanol during maturation and modified atmosphere storage of litchi fruit. Postharvest Biol. Technol. 26:157-165.

SAS Institute. 2002. SAS for Windows, version 9.2. SAS Institute, Inc., Cary, NC.

Shi, J., J. Sun, X. Wei, J. Shi, G. Cheng, M. Zhao, J. Wang, B. Yang, and Y. Jiang. 2008. Identification of (-)-epicatechin as the direct substrate for polyphenol oxidase from longan fruit pericarp. LWT-Food Sci. Technol. 41: 1742-1747.

Sodchit, C., T. Kongbangkerd, and W.N. Phun. 2008. Prevention of enzymatic browning of postharvest longan fruit by $\mathrm{N}$-acetyl-L-cysteine and 4-hexylresorcinol. Songklanakarin J. Sci. Technol. 30:31-35.

Su, X., Y. Jiang, X. Duan, H. Liu, Y. Li, W. Lin, and Y. Zheng. 2005. Effects of pure oxygen on the rate of skin browning and energy status in longan fruit. Food Technol. Biotechnol. 43: 359-365.

Tian, S., Y. Xu, A. Jiang, and Q. Gong. 2002. Physiological and quality responses of longan fruit to high $\mathrm{O}_{2}$ or high $\mathrm{CO}_{2}$ atmospheres in storage. Postharvest Biol. Technol. 24:335340 .

Tongdee, S.C. 1997. Longan, p. 335-345. In: Mitra, S. (ed.). Postharvest physiology and storage of tropical and subtropical fruits. $\mathrm{CAB}$ Intl., Wallingford, United Kingdom.

Wall, M.M. 2006. Ascorbic acid and mineral composition of longan (Dimocarpus longan), lychee (Litchi chinensis), and rambutan (Nephelium lappaceum) cultivars grown in Hawaii. J. Food Comp. Anal. 19:655-663.

Wall, M.M., K.A. Nishijima, L.M. Keith, and M.A. Nagao. 2010. Postharvest practices for managing the quality of longans and rambutans. Acta Hort. 880:473-480.

Yang, B., J. Yueming, J. Shi, F. Chen, and M. Ashraf. 2010. Extraction and pharmacological properties of bioactive compounds from longan (Dimocarpus longan Lour.) fruit-A review. Food Res. Intl. doi:10.1016/j.foodres.2010 10.019 . 